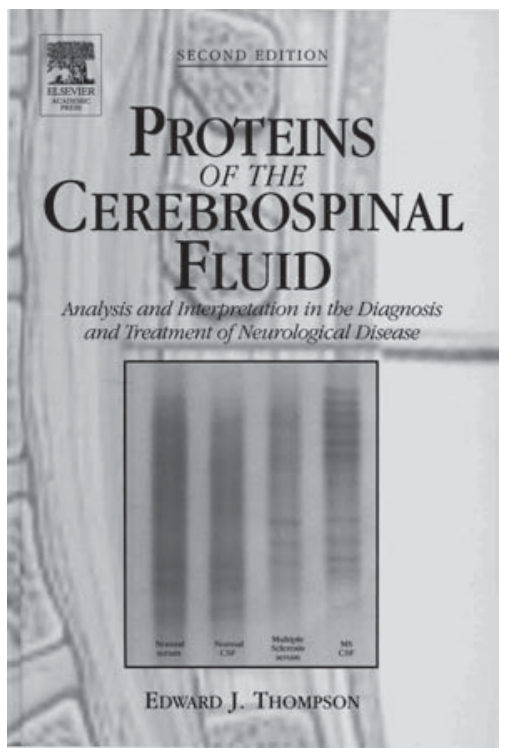

\section{Proteins of the Cerebrospinal Fluid}

\section{Analysis and Interpretation in the Diagnosis and Treatment of Neurological Disease}

Second Edition, Edward J. Thompson, Elsevier Academic Press, 2005

Željka Vogrinc

Klinički zavod za laboratorijsku dijagnostiku, Klinički bolnički centar „Zagreb“, Zagreb Clinical Institute of Laboratory Diagnostic, Clinical Hospital Center Zagreb, Zagreb, Croatia
Sedamnaest godina nakon prvog izdanja, profesor E. J. Thompson objavljuje drugo izdanje knjige o proteinima u cerebrospinalnoj tekućini. Za razliku od sličnih knjiga o ovoj problematici koje su pisali kliničari, autor piše sa stajališta biokemičara, pa je i pristup više analitički, a manje klinički.

Najveći dio knjige je posvećen imunoglobulinima u cerebrospinalnoj tekućini, posebice dokazivanju i značenju oligoklonskih imunoglobulina, dok su ostali proteini stavljeni u drugi plan i daje im se malo prostora u knjizi.

Knjiga je podijeljena na četiri dijela. U prvom dijelu autor daje pregled proteina normalne cerebrospinalne tekućine, njihovo podrijetlo u likvoru, koncentracijske odnose sa serumom, te prolazak kroz barijere. U posebnom poglavlju autor raspravlja o prednostima i nedostatcima kvantitativnih u odnosu na kvalitativne analize proteina, s posebnim naglaskom na imunoglobulinima.

U drugom dijelu knjige podrobno je predstavljen pregled matematičkih modela za evaluaciju podrijetla lgG u cerebrospinalnoj tekućini, te postavljena ideja o omjeru albumina i lgG u cerebrospinalnoj tekućini i serumu kao biološki najstabilnijoj mjeri za normalnu funkciju barijere. Za one koji se počinju baviti likvorskom dijagnostikom zanimljive su i korisne informacije o postojanju cirkadijskog ritma u lučenju cerebrospinalne tekućine, sa šesterostruko većim lučenjem noću.

Treći dio knjige je zamišljen kao priručnik za diferencijalnu dijagnostiku pojedinih neuroloških bolesti. Naglasak je na metodama dokazivanja oligoklonskih imunoglobu-
Seventeen years after the first edition, professor E.J. Thompson published the second edition of 'Proteins of the cerebrospinal fluid'. Compared to other books covering the topic of proteins in CSF, this one is written more from the biochemical and less from clinical point of view.

The major part of the book is dedicated to immunoglobulins in cerebrospinal fluid, particularly to detection and significance of oligoclonal immunoglobulins, while all other proteins are not covered extensively.

The book is divided in four parts. The first part deals with proteins normally present in cerebrospinal fluid, their origin, crossing of barriers and serum concentration ratios. A separate chapter is dedicated to advantages and disadvantages of quantitative versus qualitative methods in protein analysis, with particular emphasis on immunoglobulins.

The second part of the book covers in detail the mathematical models used for evaluating the origin of IgG in cerebrospinal fluid. The author postulates that serum/CSF albumin and IgG ratio is the biologically most suitable parameter in evaluating normal barrier function. For beginners in CSF diagnostics, useful information can be found, e.g. on diurnal variations in CSF secretion, with six-fold increase during night hours.

The third part of the book could serve as a manual for differential diagnostics of particular neurological disorders. The emphasis is again on methods available for detection of oligoclonal immunoglobulins, as well as on detection of antigen specific antibodies or their specific indexes. Ot 
lina kao i detekciji antigen-specifičnih antitijela, odnosno određivanju indeksa specifičnih antitijela. 0 "neimunoglobulinskim" proteinima govori se dosta šturo uz zaključak da većina "nervno-specifičnih" proteina koje se smatralo potencijalnim dijagnostičkim biljezima (kao npr. mijelinski bazični protein) nisu ispunili očekivanja, ali da njihovo određivanje ima prognostičku vrijednost.

Četvrti dio knjige je laboratorijski mini-priručnik i sadrži potanko opisane protokole za identifikaciju proteina cerebrospinalne tekućine pomoću različitih elektroforetskih tehnika, kao i najčešće probleme koji se pritom javljaju. To daje posebnu vrijednost knjizi jer autorovi komentari i prijedlozi proizlaze iz vlastitoga dugogodišnjeg bavljenja ovom problematikom.

Knjiga ima impresivan popis literature (1322 literaturna izvora!) s posebno izdvojenim popisom izvora za pojedine pojmove koji su poredani abecednim redom, te predstavlja odličan izvor informacija svima koji se počinju baviti ili se već bave proteinima, a posebice imunoglobulinima $u$ cerebrospinalnoj tekućini. her "non immunoglobulin" proteins are covered in detail, with general conclusion being that most "nerve specific" proteins, once considered potential diagnostic markers (such as myelin basic protein), have not fulfilled the expectations and could be used only as prognostic markers.

The fourth part of the book is actually a small laboratory manual which describes in detail the protocols for CSF protein identification using various electrophoretic techniques. It also deals with common problems that occur with these laboratory methods. This fact gives added value to the book, since author's comments and suggestio$\mathrm{ns}$ are clearly the consequence of years of experience in the field.

The book has an impressive reference list (1322 items!) with separated alphabetic reference list for particular items, which serves as a great information source for anyone who is entering the field of CSF proteins, particularly immunoglobulins. 